\title{
UJI PARSIAL CASH RATIO, DEBT TO EQUITY RATIO DAN TOTAL ASSETS TURNOVER TERHADAP RETURN ON ASSETS PADA PERUSAHAAN TRANSPORTASI YANG TERDAFTAR DI BURSA EFEK INDONESIA
}

\author{
Rina Milyati Yuniastuti \\ STIE Prasetiya Mandiri Lampung \\ rinamilyati@gmail.com
}

\begin{abstract}
Partial test to cash ratio, debt to equity ratio, total assets turnover to return on Assets on the transport company gives to return on assets. The three ratio on cash ratio, debt to equity rasio and total asset tunover as independent variable has a partial effect on return on assets as dependent variabel. And for three ratio can influence assets to company, so company can effective in the profit.
\end{abstract}

Keywords: Cash Ratio, Debt To Eqiuty Ratio, Total Assets Turnover, Return On Assets

\section{PENDAHULUAN}

Perusahaan Transportasi merupakan perusahaan yang banyak diperlukan masyarakat. Apalagi bagi mereka yang belum mempunyai kendaraan sendiri.Transportasi menjadikan suatu perusahaan yang sangat dibutuhkan oleh masyarakat. Perusahaan ini harus menjadikan suatu perusahaan yang harus dapat memenuhi kebutuhan masyarakat secara luas.Hal ini maka perusahaan harus lebih inovatif dan mampu mengambil kebijakan-kebijakan yang tepat melalui pemanfaatan seluruh potensi sumberdaya perusahaan. Salah satu kebijakan dapat dilihat dari Analisis rasio memungkinkan manajer keuangan dan pihak yang berkepentingan untuk mengevaluasi kondisi keuangan dan pihak yang berkepentingan untuk mengevaluasi kondisi keuangan akan menunjukkan kondisi sehat tidaknya perusahaan. Untuk itu diperlukan suatu data seperti laporan keuangan.Laporan keuangan dibuat sesuai dengan kaidah keuangan yang berlaku agar mampu menunjukkan kondisi dan posisi keuangan yang sesungguhnya. Laporan keuangan juga harus dibuat sesuai dengan aturan yang berlaku sehingga mudah dibaca, dipahami, dan dimengerti oleh berbagai pihak yang berkepentingan, terutama pihak pemilik usaha dan manajemen. Dengan Laporan keuangan, setiap orang dapat memahami kondisi dan posisi keuangan perusahaan yang terjadi saat ini, Kasmir (2014 : 3).Laba yang didapatkan oleh suatu perusahaan tersebut dapat diukur melalui perhitungan return on investment (ROI) atau biasa juga disebut dengan return on asset (ROA) perusahaaan, karena return on Assets tersebut dapat dipergunakan untuk mengukur tingkat efektifitas suatu perusahaan dalam menghasilkan suatu laba dengan melihat dari keseluruhan operasi perusahaan atau dari laba bersih yang didapatkan oleh suatu perusahaan. Besarnya suatu ROA/ROI dipengaruhi oleh dua faktor, diantaranya:

1. Turnover dari operating assets (tingkat peputaran aktiva yang digunakan untuk operasi), 
2. Profit margin, yaitu besarnya keuntungan operasi yang dinyatakan dalam persentase dan jumlah penjualan bersih. Profit margin ini mengukur tingkat keuntungan yang dapat dicapai oleh perusahaan dihubungkan dengan penjualannya, Munawir (2010:89).

Dalam penelitian ini,analisis rasio juga digunakan untuk menghubungkan unsur-unsur rencana dan perhitungan laba rugi sehingga dapat menilai efektivitas dan efisiensi perusahaan. Untuk laba perusahaan itu sendiri diukur melalui ROA (Return On Assets) .ROA digunakan untuk mengukur efektivitas perusahaan di dalam menghasilkan keuntungan dengan memanfaatkan ekuitas yang dimilikinya. Dalam menjalankan operasionalnya, setiap perusahaan menginginkan keuntungan (laba). Pengertian laba menurut Harahap (2010:263) yang penting dalam laporan keuangan antara lain :

a. laba merupakan dasar dalam perhitungan pajak, pedoman dalam menentukan kebijakan investasi dan pengambilan keputusan, dasar dalam peramalan laba maupun kejadian ekonomi perusahaan lainnya dimasa yang akan datang, dasar dalam perhitungan penilaian prestasi atau kinerja".

b. Pertumbuhan laba menjadi informasi yang sangat penting bagi banyak orang, yang antaralain adalah penguasa, analis keuangan, pemegang saham, ekonomi dan sebagainya. Tujuan utama pelaporan laba adalah memberikan inforrmasi yang berguna bagi mereka yang paling berkepentingan dalam laporan keuangan.Pertumbuhan laba dari tahun ketahun juga dijadikan sebagai dasar efisiensi manajemen dan membantu meramalkan arah masa depan baik perusahaan ataupun pembagian dividen.

Tujuan dari penelitian ini adalah untuk mengetahui: 1) uji parsial cash rasio terhadap return on assets pada perusahaan transportasi, 2) uji parsial debt to equity rasio terhadap return on assets pada perusahaan transportasi, 3) uji parsial total assets turnover terhadap return on assets pada perusahaan transportasi.

\section{REVIEW LITERATUR DAN HIPOTESIS}

Analisis laporan keuangan bisa digunakan untuk menilai kinerja suatu peusahaan.Analisis Laporan Keuangan merupakan suatu proses untuk membedah laporan keuangan ke dalam unsurunsurnya dan menelaah masing-masing dari unsur tersebut dengan tujuan untuk memperoleh pengertian dan pemahaman yang baik dan tepat atas laporan keuangan itu sendiri.

Menganalisis laporan keuangan berarti menilai kinerja suatu perusahaan, baik secara internal maupun untuk membandingkan dengan perusahaan lain yang berada dalam industri yang sama. Hal ini berguna bagi arah perkembangan perusahaan dengan mengetahui seberapa efektif operasi perusahaan telah berjalan. Analisis laporan keuangan sangat berguna tidak hanya bagi internal perusahaan saja, tetapi juga bagi investor dan pemangku kepentingan lainnya.

Analisis laporan keuangan merupakan suatu metode yang membantu para pengambil keputusan untuk mengetahui kekuatan dan kelemahan perusahaan melalui informasi yang didapat dari laporan keuangan. Analisis laporan keuangan dapat membantu manajemen untuk mengidentifikasi kekurangan atau kelemahan yang ada dan kemudian membuat keputusan yang rasional untuk memperbaiki kinerja perusahaan dalam rangka mencapai tujuan perusahaan. Analisis laporan keuangan juga berguna bagi investor dan kreditor dalam pengambilan keputusan investasi, Hery (2015 : 490-491).

Bagi pihak pemilik dan manajemen, tujuan utama analisis laporan keuangan adalah agar dapat mengetahui posisi keuangan perusahaan saat ini. Dengan mengetahui posisi keuangan secara mendalam, akan terlihat apakah perusahaan 
Uji Parsial Cash Ratio, Debt To Equity Ratio Dan Total Assets Turnover Terhadap Return On Assets

dapat mencapai target yang telah direncanakan sebelumnya atau tidak, Kasmir (2014 - 66). Rasio keuangan merupakan kegiatan membandingkan angka-angka yang ada dilaporan keuangan dengan cara membagi satu angka dengan angka lainnya. Perbandingan dapat dilakukan antara satu komponen dengan komponen dalam satu laporan keuangan atau antarkomponen yang ada di antara laporan keuangan. Kemudian angka yang diperbandingkan dapat berupa angka-angka dalam satu periode maupun beberapa periode. Analisis rasio merupakan bagian dari analisis keuangan. Analisis rasio adalah analisis yang dilakukan dengan menghubungkan berbagai perkiraan yang ada pada laporan keuangan dalam bentuk rasio keuangan. Analisis rasio keuangan ini dapat mengungkapkan hubungan yang penting antar perkiraan laporan keuangan dan dapat digunakan untuk mengevaluasi kondisi keuangan dan kinerja perusahaan.Dengan membandingkan rasio keuangan perusahaan dari tahun ke tahun, seorang analis dapat mempelajari komposisi perubahan yang terjadi dan menentukan apakah terdapat kenaikan atau penurunan kondisi keuangan dan kinerja perusahaan selama waktu tersebut. Selain itu, dengan membandingkan rasio keuangan suatu perusahaan terhadap perusahaan lainnya yang sejenis atau terhadap rata-rata industri dapat membantu mengidentifikasikan adanya penyimpangan atau tidak, Hery (2015 : 510-511).

Berdasarkan sumber datanya maka angka rasio dapat dibedakan antara:

a. Rasio-rasio neraca yang tergolong dalam kategori ini adalah semua rasio yang semua datanya diambil atau bersumber pada neraca, misalnya current ratio, dan acid test ratio.

b. Rasio-rasio laporan laba-rugi, yaitu angkaangka rasio yang dalam penyusunannya semua data diambil dari Laporan Rugi-Laba, misalnya gross profit margin, net operating margin, operating ratio dan lain sebagaianya.

c. Rasio-rasio antar laporan ialah semua angka rasio yang penyusunan, datanya berasal dari neraca dan data lainnya dari Laporan RugiLaba, misalnya tingkat peputaran persediaan (inventory turnover), tingkat peputaran piutang (account receivable turnover), sales to inventory, sales to fixed assets dan lain sebagainya.

Tujuan tiap penganalisa pada umumnya adalah untuk mengetahui tingkat profitabilitas, solvabilitas dan likuiditas dari perusahaan yang bersangkutan, oleh karena itu angka-angka rasio pada dasarnya juga dapat digolongkan antara (1) rasio-rasio likuiditas, (2) rasio-rasio solvabilittas, (3) rasio-rasio profitabilitas dan rasio-rasio lain yang sesuai dengan kebutuhan penganalisa misalnya rasio aktivitas, Munawir (2010 : 68-69).

\section{Rasio Likuiditas}

Fred Wedson menyebutkan bahwa rasio likuiditas merupakan rasio yang menggambarkan kemampuan perusahaan dalam memenuhi kewajiban (utang) jangka pendek. Artinya, apabila perusahaan ditagih, perusahaan akan mampu untuk memenuhi utang tersebut terutama utang yang sudah jatuh tempo.Rasio likuiditas atau sering disebut dengan nama rasio modal kerja merupakan rasio yang digunakan untuk mengukur seberapa likuidnya suatu perusahaan. Caranya adalah dengan membandingkan komponen yang ada dineraca, yaitu surat total aktiva lancar dnegan total passiva lancar (utang jangka pendek). Penilaian dapat dilakukan untuk beberapa periode sehingga terlihat perkembangan likuiditas perusahaan dari waktu ke waktu. Terdapat dua hasil penilaian terhadap pengukuran rasio likuiditas, yaitu apabila perusahaan mampu memenuhi kewajibannya, dikatakan perusahaan tersebut dalam keadaan likuid. Sebaliknya, apabila perusahaan tidak mampu memenuhi kewajiban tersebut, dikatakan perusahaan dalam keadaan ilikuid, Kasmir (2014 : 129-130).

Jenis-jenis rasio likuiditas yang dapat digunakan perusahaan untuk mengukur kemampuan, yaitu: 
a) Rasio Lancar (Current Ratio)

Rasio lancar (current ratio) merupakan rasio untuk mengukur kemampuan perusahaan dalam membayar kewajiban jagka pendek atau uang yang segera jatuh tempo pada saat ditagih secara keseluruhan. Rasio lancar (current ratio) juga merupakan harta perusahaan yang dapat dijadikan uang dalam waktu singkat (maksimal satu tahun). Komponen aktiva lancar meliputi kas, bank, surat-surat berharga, piutang, sediaan, biaya dibayar dimuka, pendapatan yang masih harus diterima, pinjaman yang diberikan, dan aktiva lancar lainnya, Kasmir (2014 :134).

Berikut rumus untuk mencari rasio lancar(current ratio):

Aktiva Lancar

\section{Utang Lancar}

b) Rasio Sangat Lancar (Quick Ratio atau Acid Test Ratio)

Rasio sangat lancar atau rasio cepat merupakan rasio yang digunakan untuk mengukur kemampuan perusahaan dalam memenuhi kewajiban jangka pendeknya yang segera jatuh tempo dengan menggunakan aset sangat lancar (kas + sekuritas jangka pendek + piutang), tidak termasuk persediaan barang dagang dan aset lancar lainnya. Dengan kata lain, rasio sangat lancar ini menggambarkan seberapa besar jumlah ketersediaan aset sangat lancar (diluar persedian barang dan aset lancar lainnya) yang dimiliki perusahaan dibandingkan dengan total kewajiban lancar. Oleh sebab itu, rasio sangat lancar ini dihitung sebagai hasil bagi antara aset sangat lancar (aset yang dapat dengan segera dikonversi menjadi kas tanpa mengalami kesulitan) dengan total kewajiban lancar, Hery (2015 : 530).
Berikut rumus untuk mencari rasio sangat lancar:

Kas + Sekuritas Jangka Pendek + Piutang

Kewajiban Lancar

c) Rasio Kas (Cash Ratio)

Rasio kas atau cash ratio merupakan alat yang digunakan untuk mengukur seberapa besar uang kas yang tersedia untuk membayar utang. Ketersediaan uang kas dapat ditujunjukkan dari tersedianya dan kas atau yang setara dengan kas seperti rekening giro atau tabungan di bank (yang dapat ditarik setiap saat). Dapat dikatakan rasio ini menunjukkan kemampuan sesungguhnya bagi perusahaan untuk membayar utang-utang jangka pendeknya, Kasmir (2014 : 139).Rasio kas merupakan rasio yang digunakan untuk mengukur seberapa besar uang kas atau setara kas yang tersedia untuk membayar utang jangka pendek. Rasio ini menggambarkan kemampuan perusahaan yang seseungguhnya dalam melunasi kewajiban lancarnya yang akan segera jatuh tempo dengan menggunakan uang kas atau setara kas yang ada. Kas meliputi uang logam, uang kertas, cek, wesel pos, dan deposito. Perangko bukanlah merupakan kas melainkan biaya yang dibayar dimuka atau beban yang ditangguhkan. Beberapa perusahaan menggunakan istilah "kas dan setara kas" dalam melaporkan kasnya.

Kas terdiri dari uang kas yang disimpan di bank (cash in bank). Sedangkan setara kas adalah investasi jangka pendek yang sangat likuid, yang dapat dikonversi atau dicairkan menjadi uang kas dalam jangka waktu yang sangat segera, biasanya kurang dari tiga bulan (90 hari). Investasi ini memang pada awalnya sengaja dilakukan oleh perusahaan dengan maksud untuk memperoleh pendapatan bunga dan uang kasnya yang sementara waktu memang berlebih atau tidak terpakai dalam 
Uji Parsial Cash Ratio, Debt To Equity Ratio Dan Total Assets Turnover Terhadap Return On Assets

kegiatan operasional perusahaan, Hery (2015 : 531-532).

Berikut adalah rumus yang digunakan untuk menghitung rasio kas:

\section{Cash And Cash Equivalent}

Current Liabilities

d) Rasio Peputaran Kas (Cash Ratio Turnover) Menurut James O. Gill, rasio peputaran kas berfungsi untuk mengukur tingkat kecukupan modal kerja perusahaan yang dibutuhkan untuk membayar tagihan dan membiayai penjualan. Artinya rasio ini digunakan untuk mengukur tingkat ketersediaaan kas untuk membayar tagihan (utang) dan biaya-biaya yang berkaitan dengan penjualan, Kasmir (2014 : 140).

Berikut rumus untuk mencari rasio peputaran kas:

Penjualan Bersih

Modal Kerja

e) Inventory to Net Working Capital

Inventory to net working capital merupakan rasio yang digunakan untuk mengukur atau membandingkan antara jumlah sediaan yang ada dengan modal kerja perusahaan. Modal kerja tersebut terdiri dari pengurangan antara aktiva lancat dengan utang lancar, Kasmir (2014 :141-142),

$$
\frac{\text { Persediaan }}{\text { Aset Lacar + Utang Lancar }}
$$

\section{Rasio Solvabilitas}

Untuk menjalankan operasinya setiap perusahaan memiliki berbagai kebutuhan, terutama yang berkaitan dengan dana agar perusahaan dapat berjalan sebagaimana mestinya. Dana selalu dibutuhkan untuk menutupi seluruh atau sebagian dari biaya yang diperlukan, baik dana jangka pendek maupun jangka panjang.
Dana juga dibutuhkan untuk melakukan ekspansi atau perluasan usaha atau investasi baru. Artinya di dalam perusahaan harus selalu tersedia dana dalam jumlah tertentu sehingga tersedia pada saat dibutuhkan.

Oleh karena itu, mengingat penggunaan salah satu dari dana tersebut memiliki kelebihan dan kekurangan, perlu disiasati agar dapat saling menunjang. Caranya adalah dengan melakukan kombinasi dari masing-masing sumber dana. Besarnya pengguanaan masing-masing sumber dana harus dipertimbangkan agar tidak membebani perusahaan, baik jangka pendek maupun jangka panjang. Dengan kata lain, penggunaan dana yang bersumber dari pinjaman harus dibatasi. Kombinasi dari penggunaan dana dikenal dengan nama rasio penggunaan dana pinjaman atau utang atau dikenal dengan nama rasio solvabilitas atau rasio leverarge.

Rasio solvabilitas merupakan rasio yang digunakan untuk mengukur sejauh mana aktiva perusahaan dibiayai dengan utang. Artinya berapa besar beban utang yang ditanggung perusahaan dibandingkan dengan aktivanya. Dalam arti luas dikatakan bahwa rasio solvabilitas digunakan untuk mengukur kemampuan perusahaan untuk membayar seluruh kewajibannya, baik jangka pendek maupun jangka panjang apabila perusahaan dibubarkan (dilikuidasi), Kasmir (2014 :150-151). Adapun jenis-jenis rasio solvabilitas yang ada dalam rasio solvabilitas antara lain:

a) Debt to Asset Rastio (Debt Ratio)

Merupakan rasio utang yang digunakan untuk mengukur perbandingan antara total utang dengan total aktiva. Dengan kata lain, seberapa besar aktiva perusahaan dibiayai oleh utang atau seberapa besar utang perusahaan berpengaruh terhadap pengelolaan aktiva.

Dari hasil pengukuran, apabila rasionya tinggi, artinya pendanaan dengan utang semakin banyak, maka semakin sulit bagi perusahaan untuk memperoleh tambahan pinjaman karena 
dikhawatirkan perusahaan tidak mampu menutupi utang-utangnya dengan aktiva yang dimilikinya. Dengan demikian pula apabila rasionya rendah, semakin kecil perusahaan dibiayai dengan utang, Kasmir (2014 : 156).

Debt ratio atau rasio utang terhadap aset merupakan rasio yang digunakan untuk mengukur perbandingan antara total utang dengan total aset. Dengan kata lain, rasio ini digunakan untuk mengukur perbandingan antara total utang dengan total aset. Dengan kata lain, rasio ini digunakan untuk mengukur seberapa besar aset perusahaan dibiayai oleh utang, atau seberapa besar utang perusahaan berpengaruh terhadap pembiayaan aset.

Membandingkan antara jumlah kewajiban dengan jumlah aset yang dimiliki perusahaan menunjukkan sejauh mana dan yang dipinjam telah digunakan untuk membeli aset. Rasio ini seringkali digunakan untuk mengukur kemampuan perusahaan dalam melunasi seluruh kewajibannya. Semakin tinggi debt ratio maka semakin besar pula kemungkinan perusahaan untuk tidak dapat melunasi kewajibannya. Ketentuan umumnya adalah bahwa perusahaan seharusnya memiliki debt ratio kurang dari 0,5 namun perlu diingat juga bahwa ketentuan ini tentu saja dapat bervariasi tergantung pada masing-masing jenis industri, Hery (2015 : 541-542).

Berikut rumus untuk menghitung debt ratio: Total Utang

Total Aset

b) Debt to Equity Ratio

Merupakan rasio yang digunakan untuk menilai utang dengan ekuitas. Rasio ini dicari dengan cara membandingkan antara seluruh utang, termasuk utang lancar dengan seluruh ekuitas. Rasio ini berguna untuk mengetahui jumlah dana yang disediakan pinjaman (kreeditor) dengan pemilik perusahaaan.
Dengan kata lain, rasio ini berfungsi untuk mengetahui setiap rupiah modal sendiri yang dijadikan untuk jaminan utang.

Berikut rumus untuk mencari debt to equity ratio:

$\frac{\text { Total Utang }}{\text { Ekuitas }}$

c) Long Term Debt to Equity Ratio (LTDtER) Merupakan rasio antara utang jangka panjang dengan modal sendiri. Tujuannya adalah untuk mengukur berapa bagian dari setiap rupiah modal sendiri yang dijadikan jaminan utang jangka panjang dengan cara membandingkan antara utang jangka panjang dengan modal sendiri yang disediaakan oleh perushaan.

Berikut rumus untuk menghitung long term debt to equity ratio:

Utang Jangka Panjang

Ekuitas

d) Times Interest Earned

Menurut J. Fireed Weston merupakan rasio untuk mencari jumlah kali perolehan bunga. Rasio ini diartikan oleh James C. Van Horne juga sebagai kemampuan perusahaan untuk membayar biaya bunga, sama seperti coverage ratio.

Berikut rumus untuk menghitung times interest earned:

\section{EBIT}

\begin{tabular}{c} 
Biaya Bunga \\
atau \\
EBIT + Biaya Bunga \\
\hline
\end{tabular}

Biaya Bunga

e) Fixed Charge Coverage

Fixed charge coverage atau lingkup biaya tetap merupakan rasio yang menyerupai 
Uji Parsial Cash Ratio, Debt To Equity Ratio Dan Total Assets Turnover Terhadap Return On Assets

times interest earned ratio. Hanya saja perbedaannya adalah rasio ini dilakukan apabila perusahaan memperoleh utang jangka panjang atau menyewa aktiva berdasarkan kontrak sewa (lease contract). Biaya tetap merupakan biaya bunga ditambah kewajiban sewa tahunan atau jangka panjang.

Berikut rumus untuk menghitung fixed charge coverage:

EBIT + Biaya Bunga + Kewajiban Sewa/ Lease

Biaya Bunga + Kewajiban Sewa/ Lease

\section{Rasio Aktivitas/ Produktivitas}

Rasio aktivitas merupakan rasio yang digunakan untuk mengukur efektivitas perusahaan dalam mengatakan aktiva yang dimilikinya. Atau dapat pula dikatakan rasio ini digunakan untuk mengukur tingkat efisiensi (efektivitas) pemanfaatan sumber daya perusahaan. Efisiensi yang dilakukan misalnya di bidang penjualan, sediaan, penagihan piutang dan efisiensi dibidang lainnya. Rasio aktivitas juga digunakan untuk menilai kemampuan perusahaan dalam melaksanakan aktivitas sehari-hari. Dari hasil pengukuran dengan rasio aktivitas akan terlihat apakah perusahaan lebih efisien dan efektif dalam mengelola aset yang dimilikinya atau mungkin justru sebaliknya.Secara umum apabila seluruh rasio aktivitas yang ada digunakan, akan mampu memperlihatkan efektivitas perusahaan secara meksimal, jika dibandingkan dengan penggunaan hanya sebagaian saja. berikut ini beberapa jenisjenis rasio aktivitas dari beberapa ahli keuangan, yaitu:
a) Peputaran Piutang (Receivable Turnover)

Peputaran piutang merupakan rasio yang diguakan untuk mengukur berapa lama penagihan piutang selama satu periode atau beberapa kali dana yang ditaam dalam piutang ini berputar dalam satu periode.
Berikut rumus untuk mencari peputaran piutang:

$$
\frac{\text { Penjualan Kredit }}{\text { Piutang }}
$$

b) Peputaran Sediaan (Inventory Turnover)

Peputaran sediaan merupakan rasio yang digunakan untuk mengukur berapa kali dana yang ditanam dalam sediaan ini berputar dalam suatu periode.

Berikut rumusan perputaran sediaan:

Harga Pokok Barang yang Dijual atau Penjualan

\section{Sediaan}

c) Peputaran Modal Kerja (Working Capital Turnover)

Perputaran modal kerja merupakan salah satu rasio untuk mengukur atau menilai keefektifan modal kerja selama periode tertentu.

Berikut rumus untuk mencari peputaran modal kerja:

$\frac{\text { Penjualan Bersih }}{\text { Modal Kerja }}$

d) Fixed Asset Turover

Fixed asset turnover merupakan rasio yang digunakan untuk mengukur berapa kali dana yang ditanamkan dalam aktiva tetap berputar dalam satu periode.

Berikut rumus untuk mencari fixed asset turnover:

Penjualan

\section{Total Aktiva Tetap}

e) Total assets turnover

Merupakan rasio yang digunakan untuk mengukur perputaran semua aktiva yang dimiliki perusahaan dan mengukur berapa jumlah penjualan yang diperoleh dari tiap rupiah aktiva, Kasmir (2010 : 185). 
Total assets turnover disebut juga dengan perputaran total aset. Rasio ini meliat sejauh mana keseluruhan aset yang dimiliki oleh perusahaan terjadi peputaran secara efektif (Fahmi, 2011 : 135).Peputaran total aset (total assets turnover) juga merupakan rasio yang digunakan untuk mengukur keefektifan tpotal aset yang dimiliki perusahaan dalam menghasilkan penjualan, atau dengan kata lainuntuk mengukur berapa jumlah penjualan yang akan dihasilkan dari setiap rupiah dan yang tertanam dalam total aset. Rasio ini dihitung sebagai hasil bagi antara besarnya penjualan (tunai maupun kredit) dengan rata-rata total aset. Yang dimaksud dengan rata-rata total aset adalah total aset awal tahun ditambah total aset akhir tahun lalu dibagi dengan dua. Peputaran total aset yang rendah berarti perusahaan memiliki kelebihan total aset, di manan total aset yang ada belum dimanfaatkan secara maksimal untuk menciptakan penjualan, Heri (2015 : 221).Total assets turnover atau operating assets turnover merupakan rasio antara jumlah aktiva yang digunakan dalam operating assets terhadap jumlah penjualan yang diperoleh selama periode tertentu. Rasio ini merupakan ukuran tentang seberapa jauh aktiva ini telah dipergunakan di dalam kegiatan perusahaan atau menunjukkan berapa kali operating assets berputar dalam satu periode tertentu, biasanya dalam periode satu tahun. Dalam menganalisa menggunakan rasio ini, sebaiknya diperbandingkan selama beberapa tahun sehingga diketahui trend daripada penggunaan operating assets. Suatu trend angka rasio yang cenderung naik mampu memberikan gambaran bahwa perusahaan semakin efisien dalam menggunakan aktiva. Dalam menaksirkan rasio ini, harus hati-hati karena rasio ini mempunyai beberapa kelemahan antara lain:

(1) Rasio ini hanya menunjukkan hubungan antara penghasilan (sales revenue) dengan aktiva yang dipergunakan dan tidak memberikan gambaran tentang laba yang diperoleh.
(2) Penjualan adalah untuk satu periode, sedang total operating assets merupakan akumulasi kekayaan perusahaan selama beberapa periode, mungkin adanya expansi yang tidak segera dapat menghasilkan tambahan penjualan sehingga rasio pada tahun pertama adanya expansi menunjukkan rasio yang rendah.

(3) Bahwa tingkat penjualan yang diperoleh mungkin sekali dipengaruhi oleh berbagai faktor di luar kemampuan perusahaan untuk diatasi (uncontrollable).

Untuk menghindari kelemahankelemahan operating turnover assets ini, turnover ini biasa dihubungkan dengan tingkat profit yang diperoleh atau profit marginnya, yang diperoleh dengan cara membagi profit yang diperoleh dengan total penjualan netto. Turnover yang tinggi menunjukkan manajemen yang efektif tetapi dapat juga turnover yang tinggi disebabkan aktiva perusahaan yang sudah tua dan sudah habis disusut, jadi turnover yang tinggi ini terjadi karena keadaan perusahaan. Sehingga turnover ratio saja tidak dapat memberikan gambaran yang pasti tentang keefektifan kegiatan perusahaan dan harus dihubungkan dengan profit marginnya sehingga diperoleh rate of returnnya (return on investen), Munawir (2010 : 88).

Berikut rumus untuk mencari total assets turnover adalah sebagai berikut:

\section{Sales}

Total Assets

\section{Rasio Profitabilitas}

Rasio profitabilitas merupakan rasio untuk memulai kemampuan perusahaan dalam mencari keuntungan. Rasio ini juga memberikan ukuran tingkat efektivitas manajemen suatu perusahaan. Hal ini ditujukkan oleh laba yang dihasilkan dari penjualan dan pendapatan investasi. Intinya adalah penggunaan rasio ini menunjukkan efisiensi perusahaan, (Kasmir, 2014 
Uji Parsial Cash Ratio, Debt To Equity Ratio Dan Total Assets Turnover Terhadap Return On Assets

: 196). Rasio ini mengukur efektifitas manajemen secara keseluruhan yang ditujukan oleh besar kecilnya tingkat keuntungan yang diperoleh dalam hubungannya dengan penjualan maupun investasi. Semakin baik rasio profitabilitas maka semakin baik menggambarkan kemampuan tingginya perolehan keuntungan perusahaan, Fahmi (2011 : 134).

a) Profit margin (profit margin on sales)

Merupakan salah satu rasio yang digunaka untuk mengukur margin laba atas penjualan. Cara pengukuran rasio ini adalah dengan membandingkan laba bersih setelah pajak dengan penjualan bersih.

(1) Untuk margin laba kotor dengan rumus:

Penjualan Bersih + Harga Pokok Penjualan

(Laba Kotor)

Penjualan

(2)Untuk margin laba bersih dengan rumus:

Laba Setelah Bunga dan Pajak (Laba Bersih)

Penjualan

b) Return On Investment (ROI)

Rasio return on investment (ROI) atau pengambilan investasi, bahwa dibeberapa referensi lainnya ditulis dengan return on total asset (ROA). Rasio ini melihat sejauh mana investasi yang telah ditanamkan mampu memberikan pengembalian keuntungan sesuai dengan yang diharapkan. Dan investasi tersebut sebenarnya sama dengan aset perusahaan yang ditanamkan atau ditempatkan, Kasmir (2014 : 201).

Rasio return on investment (ROI) atau return on total asset (ROA) juga merupakan rasio yang menunjukkan seberapa besar kontribusi aset dalam menciptakan laba bersih. Dengan kata lain, rasio ini digunakan untuk mengukur seberapa besar jumlah laba bersih yang akan dihasilkan dan setiap rupiah dana yang tertanam dalam total aset. Rasio ini dihitung dengan membagi laba bersih terhadap total aset.Semakin tinggi hasil pengambilan atas aset berarti semakin tinggi pula jumlah laba bersih yang dihasilkan dari setiap rupiah dana yang tertanam dalam total aset. Sebaliknya, semakin rendah hasil pengambilan atas aset berarti semakin rendah pula jumlah laba bersih yang dihasilkan dari setiap rupiah dana yang tertanam dalam total aset, Heri (2015:228). Besarnya suatu ROI dipengaruhi oleh dua faktor, diantaranya:

(1) Turnover dari operating assets (tingkat peputaran aktiva yang digunakan untuk operasi),

(2) Profit margin, yaitu besarnya keuntungan operasi yang dinyatakan dalam persentase dan jumlah penjualan bersih. Profit margin ini mengukur tingkat keuntungan yang dapat dicapai oleh perusahaan dihubungkan dengan penjualannya.

Usaha mempertinggi ROI dengan memperbesar assets turnover adalah kebijaksanaan investasi dana dalam berbagai aktiva, baik aktiva lancar maupun aktia tetap, Munawir (2010 : 89).

Berikut rumus rasio return on investment (ROI) atau return on total asset (ROA) adalah:

Earning After Tax (EAT)

Total Assets

atau

Total Asset Turnover x Profit Margin

c) Hasil Pengambilan Ekuitas (Return on Equity/ $R O E)$

Hasil pengambilan ekuitas atau rentabilitas modal sendiri merupakan rasio untuk mengukur laba bersih sesudah pajak dengan modal sendiri. Rasio ini menunjukkan efisiensi penggunaan modal sendiri. Semakin tinggi rasio ini, semakin baik. Artinya posisi pemilik perusahaan semakin kuat, demikian pula sebaliknya. 
Berikut rumus untuk mencari hasil pengembalian ekuitas:

Laba setelah Bunga dan Pajak

Ekuitas

\section{METODE PENELITIAN}

\section{Jenis Penelitian}

Jenis penelitian yang dilakukan penulis adalah jenis penelitian yang menggunakan metode analisis kuantitatif dan metode analisis kulitatif.

\section{Tempat Penelitian}

Tempat penelitian dilakukan di Bursa Efek Indonesia (BEI). Objek yang diteliti adalah perusahaan Transportasi yang terdaftar di BEI di tahun 2016.

Dan metode yang digunakan dalam penelitian ini adalah metode pruposive sampling. yaitu teknik pengambilan sampel sumber data, dengan pertimbangan tertentu, Sugiyono (2011 : 126). Adapun pertimbangan-pertimbangan yang digunakan adalah sebagai berikut:

1) .Perusahaan Transportasi yang terdaftar di Bursa Efek Indonesia (BEI) pada tahun 2016 2).Laporan keuangan yang menyajikan kas dan setara kas, utang lancar, total utang, total aset, penjualan, serta laba bersih yang lampirkan pada tahun 2016.

Laporan keuangan perusahaanperusahaan ini diperoleh dari www.idx.co.id.

\section{Definisi Operasional Variabel}

\section{a. Variabel dependent}

Variabel dependent yang digunakan dalam penelitian ini adalah ROA sebagai berikut:

Rasio yang menunjukkan seberapa besar kontribusi assets dalam menciptakan laba bersih

$$
\text { ROA = Laba setelah pajak } x \text { 100\% }
$$

Total Assets

\section{b.Variabel Independent}

Variabel Independent yang digunakan dalam penelitian ini adalah :

1. Cash Rasio

Rasio kas atau cash ratio merupakan alat yang digunakan untuk mengukur seberapa besar uang kas yang tersedia untuk membayar utang.

$$
\text { Cash Ratio }=\text { kas }+ \text { bank }
$$

\section{Hutang lancar}

\section{Debt to Equity Rasio}

Merupakan rasio yang digunakan untuk menilai utang dengan ekuitas. Rasio ini dicari dengan cara membandingkan antara seluruh utang, termasuk utang lancar dengan seluruh ekuitas. Rasio ini berguna untuk mengetahui jumlah dana yang disediakan pinjaman (kreeditor) dengan pemilik perusahaaan.

$$
\text { DER }=\text { Total Utang }
$$

\section{Ekuitas}

\section{Total Asset Turnover}

Merupakan rasio yang digunakan untuk mengukur perputaran semua aktiva yang dimiliki perusahaan dan mengukur berapa jumlah penjualan yang diperoleh dari tiap rupiah aktiva.

\section{TATO $=$ Sales}

Total Assets

\section{Uji Parsial atau Uji t}

Uji t pada dasarnya merupakan seberapa jauh pengaruh satu variable independent terhadap variable dependent dengan menganggap variable independent lainnya kostan, Wijaya (2012). Langkah-langkah uji t adalah sebagai berikut :

1. Menentukan Hipotesis

$\mathrm{H}_{0}$ : tidak ada pengaruh antara variabel independen terhadap variabel dependen.

$\mathrm{H}_{\mathrm{a}}$ : ada pengaruh antara variabel independen terhadap variabel dependen. 
Uji Parsial Cash Ratio, Debt To Equity Ratio Dan Total Assets Turnover Terhadap Return On Assets

2. Menentukan tingkat signifikansi

Tingkat signifikansi menggunakan 0,05 $(\alpha=5 \%)$.

3. Menentukan $\mathrm{T}_{\text {hitung }}$.

4. Menentukan $\mathrm{T}_{\text {tabel }}$

Tabel distribusi t dicari pada $\alpha=5 \%$ dengan derajat kebebasan $(\mathrm{df})=\mathrm{n}-\mathrm{k}$.

5. Kriteria pengujian

$$
\begin{aligned}
& \mathrm{H}_{0}: \text { diterima jika } \mathrm{T}_{\text {hitung }}>\mathrm{T}_{\text {tabel }} \\
& \mathrm{H}_{0} \text { : ditolak jika } \mathrm{T}_{\text {hitung }}<\mathrm{T}_{\text {tabel }}
\end{aligned}
$$

\section{HASIL PENELITIAN DAN PEMBAHASAN}

\section{Hasil Penelitian}

Berdasarkan hasil kuantitatif yang didapat dari pengolahan data melalui program SPSS versi 20 maka didapat output sebagai berikut:

\begin{tabular}{|c|c|c|c|c|c|c|}
\hline \multicolumn{7}{|c|}{ Coefficients $^{\mathrm{a}}$} \\
\hline \multirow{2}{*}{\multicolumn{2}{|c|}{$\begin{array}{l}\text { Model } \\
\text { B }\end{array}$}} & \multicolumn{2}{|c|}{$\begin{array}{c}\text { Unstandardized } \\
\text { Coefficients }\end{array}$} & \multirow[t]{2}{*}{$\begin{array}{l}\text { Standardized } \\
\text { Coefficients }\end{array}$} & \multirow[t]{2}{*}{$\mathrm{t}$} & \multirow[t]{2}{*}{ Sig. } \\
\hline & & $\begin{array}{l}\text { Std. } \\
\text { Error }\end{array}$ & Beta & & & \\
\hline \multirow{4}{*}{1} & (Constant) & 23.274 & 134.425 & & .173 & .868 \\
\hline & $\mathrm{CR}$ & .015 & .019 & .383 & .763 & .475 \\
\hline & DER & -.487 & .702 & -.349 & -.694 & .514 \\
\hline & TAT & .055 & .053 & .409 & 1.041 & .338 \\
\hline
\end{tabular}
Tabel 1.Tabel Coefficient

Menentukan T tabel dengan $\alpha=5 \%$ dan $\mathrm{Df}=\mathrm{n}-\mathrm{k}$ yaitu $\mathrm{Df}=10-3$ maka $\mathrm{Df}=7$

Sehingga dengan $\alpha=5 \%$ dan $\mathrm{df}=7$ maka T tabel sebesar 1,895

\section{Pembahasan}

\section{Cash Ratio}

merupakan alat yang digunakan untuk mengukur seberapa besar uang kas yang tersedia untuk membayar utang. Ketersediaan uang kas dapat ditujunjukkan dari tersedianya dan kas atau yang setara dengan kas seperti rekening giro atau tabungan di bank (yang dapat ditarik setiap saat).
Hasil dari t hitung pada cash rasio sebesar 0,763 dan t tabel sebesar 1,895 yang berarti Ho ditolak, karena $\mathrm{H}_{0}$ : ditolak jika $\mathrm{T}_{\text {hitung }}<\mathrm{T}_{\text {tabel. }}$ Hal ini berarti cash rasio berpengaruh terhadap return on assets.

\section{Debt to Equity Rasio atau DER}

Merupakan rasio yang digunakan untuk menilai utang dengan ekuitas. Rasio ini dicari dengan cara membandingkan antara seluruh utang, termasuk utang lancar dengan seluruh ekuitas. Rasio ini berguna untuk mengetahui jumlah dana yang disediakan pinjaman (kreeditor) dengan pemilik perusahaaan.

Hasil dari thitung pada debt to equity rasio sebesar -0,694 dan t tabel sebesar 1,895 yang berarti Ho ditolak karena $\mathrm{H}_{0}$ : ditolak jika $\mathrm{T}_{\text {hitung }}<$ $\mathrm{T}_{\text {tabel. }}$ Sehingga debt to equity rasio berpengaruh terhadap return on assets.

\section{Total AssetsTurnover}

Merupakan rasio yang digunakan untuk mengukur perputaran semua aktiva yang dimiliki perusahaan dan mengukur berapa jumlah penjualan yang diperoleh dari tiap rupiah aktiva

Hasil dari thitung pada inventory turnover sebesar 1,041 dan t tabel sebesar 1,895 yang berarti Ho ditolak karena $\mathrm{H}_{0}$ : ditolak jika $\mathrm{T}_{\text {hitung }}<$ $\mathrm{T}_{\text {tabel }}$ Sehingga total asets turnover berpengaruh terhadap return on assets

\section{KESIMPULAN DAN SARAN}

\section{Simpulan}

1. variabel Cash ratio (CR) berpengaruh terhadap ROA

2. variabel Debt to Equity Rasio (DER) berpengaruh terhadap ROA

3. variabel Total Assets Turnover (TATO) berpengaruh terhadap ROA 


\section{Saran}

Di harapkan perusahaan transportasi dapat mempertinggi ROA dengan memperbesar total assets turnover . hal ini adalah kebijaksanaan investasi dana dalam berbagai aktiva, baik aktiva lancar maupun aktiva tetap.

\section{DAFTAR PUSTAKA}

Fahmi, Irham. Analisis Laporan Keuangan, Edisi Pertama. Alfabeta. Bandung.

Hasanuh, Nanu. 2011. Akuntansi Dasar : Teori dan Praktik, Edisi Pertama. Mitra Wacana Media. Jakarta.

Hery. 2015. Analisis Laporan Keuangan, PT Buku Seru. Cet 1. Yogyakarta.
Hery. 2015. Pengantar Akuntansi Compehensive Edition "Lengkap dengan Kumpulan Soal dan Solusinya", PT Grasindo. Jakarta.

Kasmir. 2014. Analisis Laporan Keuangan, Edisi Pertama (Revisi). PT RajaGrafindo Persada. Jakarta.

Munawir. 2010. Analisa Laporan Keuangan, Edisi Keempat. Liberty. Yogyakarta.

Nasyaroeka,Jhon.SPSS for economics,Modul Pratikum SPSS.STIE Lampung

Milyati ,Rina.2017.Jurnal ilmiah Gema Ekonomi,vol.7 No.1 Februari 2017.Stie Prasetiya Mandiri Lampung. 